\title{
ADOBE VERNACULAR HOUSING TYPOLOGICAL ANALYSIS IN CALIMAYA DE DÍAZ GONZALEZ, STATE OF MEXICO
}

\author{
D.S. Romero Olguín ${ }^{1}$, L. F.Guerrero Baca ${ }^{2, *}$ \\ ${ }^{1} \mathrm{PhD}$ program in Architecture, National Autonomous University of México, México city - dromero.olguin@gmail.com \\ ${ }^{2}$ Metropolitan Autonomous University- Xochimilco, México city - luisfg1960@yahoo.es
}

\author{
Commission II - WG II/8
}

KEY WORDS: Typology, Construction techniques, Vernacular architecture, Calimaya

\begin{abstract}
:
Climate, topography, hydrology, and all the factors of the natural environment affecting a population, as well as accessibility to materials and its ease of transport have constituted the variables determining the vernacular housing characteristics. In the territory which now covers Calimaya various cultural groups settled, making evident the syncretism of various building traditions. Since its formation the place was a site of passage, which communicated various goods transport, generating a peculiar urban physiognomy and cultural exchange, leading to the introduction of buildings, typical of this place. The town's current situation is characterized by a rapid process of urbanization and social transformation, generating new needs of usage and habitability. This growth transforms the architecture of the place, replacing it with buildings with physiognomic features that do not correspond to the original context, causing loss of local construction techniques. Assuming that typology is a theoretical and creative activity allowing the definition and structuring of a system of conceptual relations, within certain limits, in order to determine the representative elements of vernacular architecture of the site, a typological analysis is being carried out to identify local materials and buildings systems, its characteristics, and spatial shape. Likewise, a constructive and architectural analysis, identifying traditional building techniques, which will favour the development of solutions facing the problem of conservation, maintenance and sustainability in the locality, is being carried out.
\end{abstract}

\section{INTRODUCTION}

This paper presents the methodology used for the creation of a typological framework representing the traditional architecture in the town of Calimaya de Diaz Gonzalez, State of Mexico, in order to generate working tools for maintaining and preserving the architectural heritage focusing on the traditional housing.

Nowadays the development of cities has modified the original traces, and regarding Calimaya, cropping areas have been transformed into paths for the removal of construction materials; the original job of constructions has been modified, leading to residential use reduction. These new needs for housing, infrastructure, services and transport, have led to a conflict between urban development and the defense of heritage for it has generated an evident alteration to the local architectural heritage. Vernacular or traditional architecture has been directly affected, being destroyed or modified to build new buildings with features that do not correspond to the original context, altering the shape and community functionality.

Thus, the preservation and rescue of the heritage starts from the identification of the traits and techniques characterizing the architecture, which can become the technical and conceptual basis of both, its rehabilitation and integration alternatives to the natural and cultural environment. Changes always happen, but transformations can be controlled and planned without jeopardizing the essential features. These qualities are those giving character and personality to the community, committed to the idea that the conservation makes sense only as an upgrade of the historical process (Guerrero, 1998).

\subsection{Objectives}

The main objective of the typological analysis is to identify the outstanding features of the architectural elements within the dynamism of the environment. The results obtained allow creating alternative preventive measures for the protection and rehabilitation of traditional architecture. In addition, it facilitates the formation of a conceptual and technical base of technological possibilities to integrate natural and cultural environment.

This methodology, applied to the rescue of the heritage, supports the idea that buildings of various ages and styles have to live together in harmony without the predominance of some over others, with the possibility of formal and functional solutions grouping them together for reuse. By identifying historical development and deterioration -common to a region or a period of time-, the proposed solutions will have balanced levels of specificity and generality; that is, if we start with the premise that it is valid to group the problems by types, we can also propose types of solutions (Guerrero, 1998).

\subsection{Methodology}

The typology is constructed on the base of the recognition of the particularities of the locality, where various scales of assets are involved to identify the distinctive features. The work begins with the analysis on a larger scale -the general features of the urban scale- and finishes with the observation in detail of particular features -the ornamental elements, or construction details.

\footnotetext{
* Corresponding author
} 
During the study, the definition of types of streets, blocks, plots, houses, buildings with heritage value, as well as the description of the components characterizing them were included. To determine the grouping formal-spatial infrastructure and constructive concepts were selected and the following methodology was used:

1. Visual tour of the place of study to establish a work polygon determined by the presence of building heritage. The working area -where there are a greater number of heritage places- was identified. From these data collection the historic center, with the north-south axis, which cuts across the location, was selected. It was noted that in the outskirts of the selected perimeter the traditional architecture has been altered irreversibly.

2. Definition of boundaries. The selected study area downtown area- has been separated in two neighborhoods, these zones have been differentiated in four areas as follows by working methodology: San Pedro-San Pablo Quarter East, San Pedro-San Pablo Quarter West and San Juan Quarter East, San Juan Quarter West.

3. Identification of valuable buildings and/or architectural elements. When performing urban research within registry maps, the presence of formal-functional features and historical materials in real estate were seen. This systematized information has allowed the preparation of planimetry identifying the density of heritage for every area of the locality; this has made possible to perform an assessment of the selected area (Figure 1).

4. Formal features description. A list with items of historical, technological and cultural value was made and such traits have enriched traditional architecture on identified samples. This information was arranged in parallel with the data that has been gathered during mapping work carried out in five properties. From these results and work notes the descriptions required were defined.

5. Worksheets. With the collected, analyzed and processed data, the worksheets have facilitated the management of information and, above all, have improved the effectiveness to identify the concepts that were developed. Graphics have been used to benefit from data processing. The characteristics - common and easy obtainable- were retrieved, so it was easy to point out the structure and typological limits for analysis.

6. Traditional architectural elements characterization. After processing of information, it is already possible to identify the materials and technology features that predominate in the Calimaya's traditional architecture. From this point in the analysis it is feasible to generate the predominant typologies.

In order to obtain a better interpretation of the results, the different work levels were simplified in a synthesis of the morphological features of the community -infrastructure, formal-spatial feature, technological structure and damages-. The latter level was carried out to be able to identify the most suitable interventions to the site.

It is important to mention that the typology has to be placed in a particular historical condition to intervene as a functional and formal analogy.

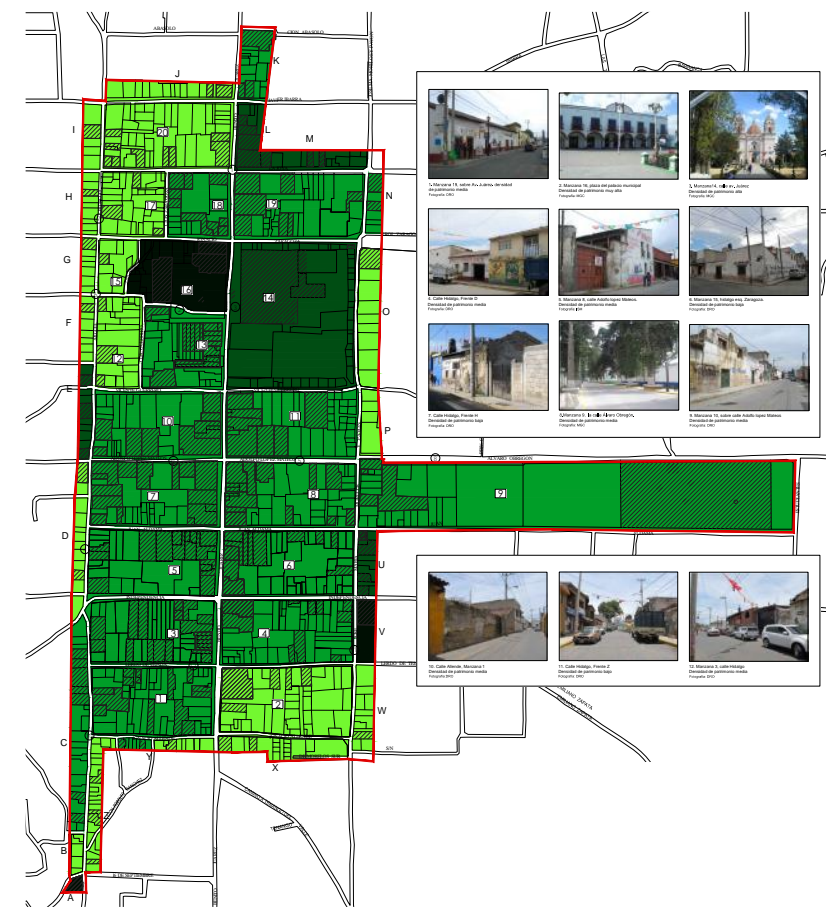

Figure 1. Heritage density level. (Source: own elaboration).

\section{CALIMAYA DE DÍAZ GONZÁLEZ}

\subsection{Geographic Location}

Calimaya is located in the State of Mexico, south of the city of Toluca, on the slopes of the Nevado de Toluca volcano. The site is a slightly sloping plain; at its highest measured 4.578 meters above sea level. In the surroundings there are several streams, springs and creeks formed during rainy season. Climate is temperate rainforest, with predominant rainfall in summer, frost from November to January and with an average annual temperature of 12 to 14 degrees Celsius (Loera Chavez, 1999).

\subsection{History}

Calimaya was founded in 800 A.D. as an pre-Columbian Altepet $^{1}$. During Spanish conquest it was a zone of great economic, strategic and military importance, which was used for the cultivation of maize and livestock thanks to the abundant water in its surroundings. In 1528 it was given as a commandery to Hernán Cortés, so the indigenous people had to pay tribute as work and home-grown products.

During the nineteenth century a greater economic development happened: the urban structure changed and there was an increase in agricultural production and commercial activity. By 1824 Calimaya was the last trade spot before Toluca City; thus, the development of the city is linear, following the main and transit road. Its main function for this time was to meet the needs of the merchant.

This period of economic boom diminished with the introduction of the railway in 1897; the new trade route was located on the outskirts of the city. The construction of the federal highway in 1927 ended up isolating the population and stopped the economic development. From that moment on houses suffer few changes in

\footnotetext{
Political entity ruled by a lied with several subject peoples.
} 
its architectural morphology. Currently it retains its reticular regular urban trace with spacious grounds, it still maintains the original scheme of the Spanish site.

\subsection{Urban Trace}

The distribution of the new cities in New Spain was premised on a square located to the center of everything, where the houses for the exercise of political power, religious service, as well as portals for trade were installed; in Calimaya this model is maintained nowadays.

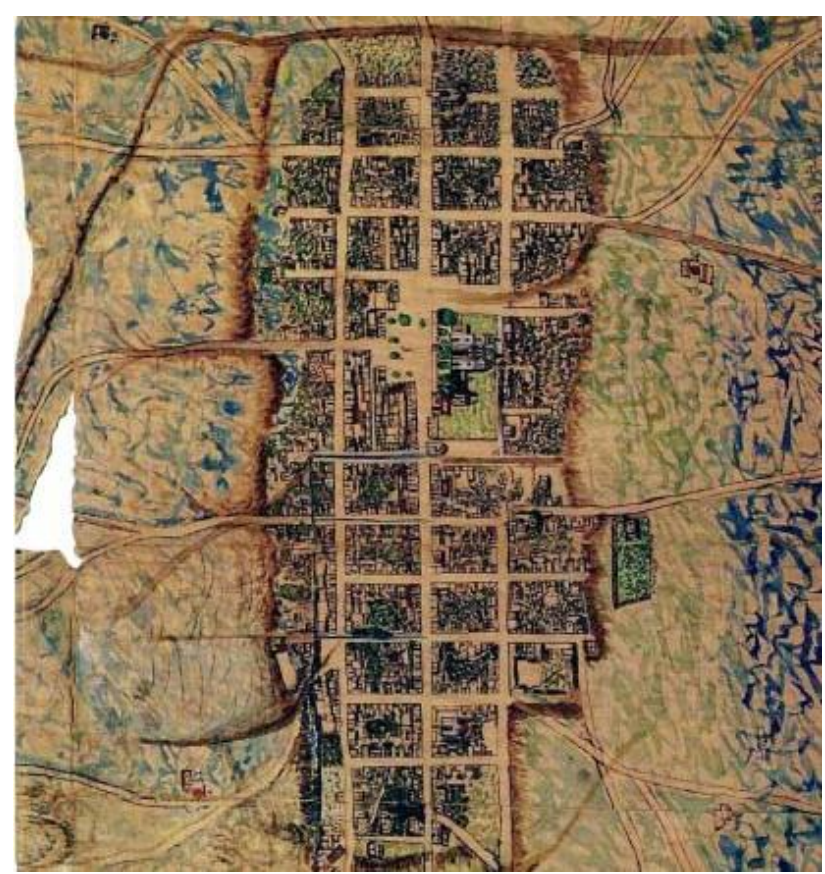

Figure 2. Sketch of the municipality of Calimaya made by C.L.F. ca. 1824. (Source: Atlas of the State of Mexico).

The urban organization of the town has maintained the particularity of being oriented in a north-south axis, with a linear path along the Avenida Juarez, which is the main route and the distributor shaft. The main larger buildings and houses have remained on this axis, while the secondary streets are distributed in parallel. In the outskirts there are livestock, agriculture and mining zones.

The properties on Avenida Juarez retain their original trace and their block centers are tree-lined boulevards where the majority of the housing estates of interest are. Outside this linear axis, blocks do not retain the same morphology, nor remains the same urban pattern where growth has been messy; likewise, some block centers have been subdivided for distributing them among the children of the ancient inhabitants (Figure 2).

\subsection{Heritage}

Regarding architectural heritage, INAH's ${ }^{2}$ National Catalog of Historical Monuments has recorded the buildings of historical and heritage value in the locality. Inside the study polygon 42 properties of value, -11 of which are religious architecture, 7 are for equipment and the rest are related to the vernacular housingwere located. During the research 152 properties of patrimonial interest that had not been considered previously by the catalog of historical monuments were identified (Table 1).

\begin{tabular}{|l|c|c|}
\hline Building type & Asset & $\%$ \\
\hline Religious & 11 & 5.55 \\
Civil & 07 & 3.53 \\
Housing & 178 & 89.9 \\
Facility & 02 & 1.02 \\
\hline Total & 198 & 100 \\
\hline
\end{tabular}

Table 1. Heritage value buildings percentage

\section{VERNACULAR HOUSING TYPOLOGICAL ANALYSIS}

The samples that were carried out on site to develop the analysis and evaluation are the basis for the identification of the architectural typology of Calimaya. A brief description of the results obtained for each of the four levels of work mentioned is made.

\subsection{Infrastructure}

The analysis result has determined that the public network services have not adapted appropriately to the historicity of the place; on the contrary, have fractured the image desirable. The facilities deteriorate the image, the pipes and water hatch directly impact on the facades of the local architecture. It is important to reiterate that these are basic services necessary for the benefit of the community. Although it is not intended to be prohibitive, standards for establishing measures of integration with the existing heritage, which does not deteriorate or affect visually to the image of the site, should operate.

No original flooring was seen; these have been replaced in secondary streets by asphalt, on main roads by stamped concrete and in the historic center by cobblestones. The sidewalks on main roads are made of quarry stone and, in minor roads, of concrete.

\subsection{Spatial-Formal Classification}

Regarding spatial organization, single level housing is the dominant element, with lofts to contain the space generated by the sloping roofs - gable roofs-, configured with very marked slopes due to weather conditions.

Two types of shape were seen, differing in the distribution in the land; the first type is the "L shape", where housing is open toward the back, connecting to the central courtyard. The second type is the "C shape", in which all rooms revolve around a hallway and a central patio. In this case there may or may not be a back yard. In all the examples, the buildings are aligned to the vertical surface of the street (Figure 3).

In the beginning, the spatial distribution in the block centers was construction free; these areas were used for vegetable gardens and animals for domestic use. Over time these spaces are disappearing and now are subdivided for the use of the other family members. In other cases they have been transformed into new buildings, so the central open spaces have been lost slowly.

Intensity of construction refers to the relationship of the house with the land to the existing percentage free area, i.e. the area of the plot without construction. The free area by land is 25 to $30 \%$, reflecting the preference of the use of courtyards to the interior to cover the needs of lighting and ventilation over the openings to the outside. Calimaya has a preference for central courtyards of 48.6 percent; then the back courtyards and in more extreme cases-there is no garden.

\footnotetext{
National Institute of Anthropology and History
} 

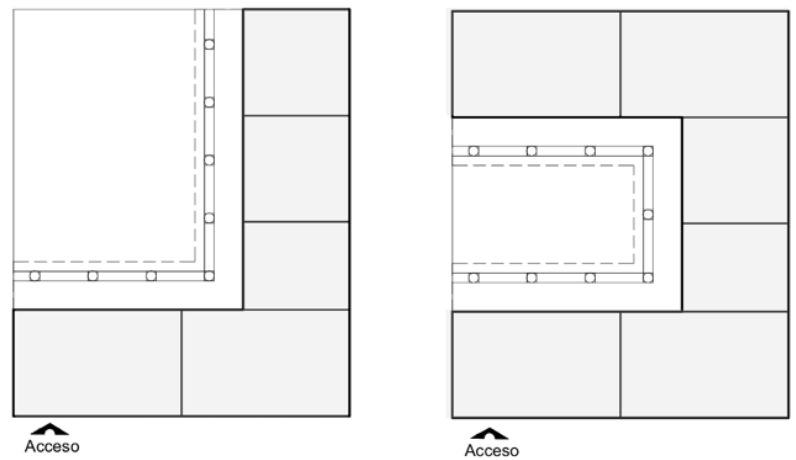

Figure 3. Shape types in Calimaya. (Source: JAPN)

The current use of buildings in more than half of all cases is mixed-use, which means that the rooms that have direct access to the street have been used as trading area; the area for housing is distributed in the interior parts, around the courtyards. Where the houses are two stories high, the ground floor space is used for trading; by dividing the space into two areas with two different levels, both housing and commerce enjoy a larger area of distribution. The rooms for the family are larger in size and commerce is independent of the private areas; the accesses are differentiated, unless it is a family business place.

Secondly, exclusively residential use; this type recurrently occurs in houses that are not on the main road, those that are located in the surrounding streets, where there is a direct contact with Avenida Juarez; however, there are a few cases on the avenue. This section allowed determining that traditional buildings still retain the use and formal characteristics dating from the eighteenth and nineteenth century, the period of greatest economic boom in the community (Figure 4).

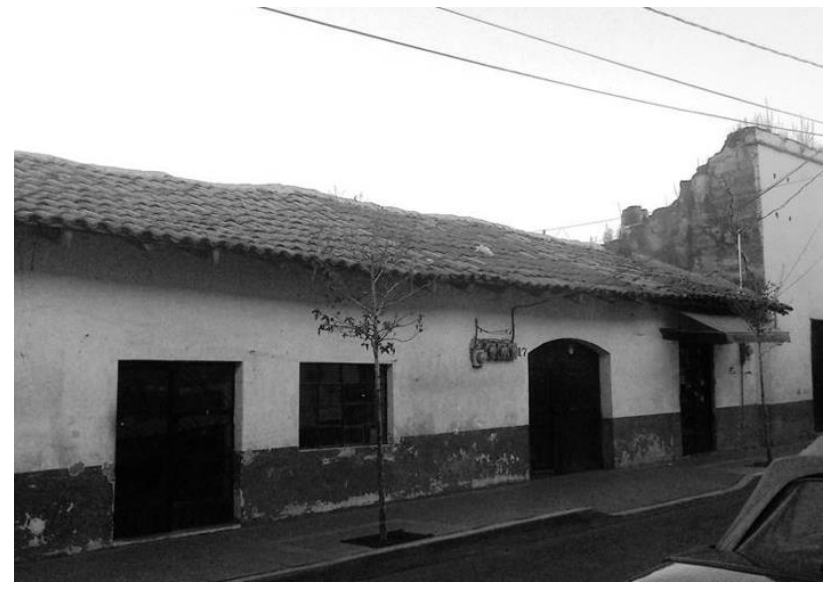

Figure 4. Vernacular architecture in the surrounding streets. (Source: DSRO)

Having performed the analysis concerning the morphology of housing in facades, the results showed that the one-story houses, with double height are the 48.6 percent of the locality; low height is due to the continuity of the telluric movements, caused by the proximity with the volcano. The second type are two-story houses; the main characteristic is that they have retained the use of the balconies with blacksmith ornaments. The covers for this typology can be either one or two pitched roofs with curved or flat clay tiles, which in many cases have already been replaced by concrete roofs (Figures 5 and 6).
As mentioned earlier, the height and foundations in traditional housing in Calimaya are a constructive constraint, because of the risks of being in the vicinity of Nevado de Toluca, seismic activity, heavy rains and, in extreme cases, even landslides.

Preventive measures to avoid damage to the estate have been taken -width of walls, low height, slope of the decks and foundations that avoid irregular shapes-. So, the heights on the facades are in two different shapes: the smaller ones with an average height of four to six meters (one story) and the larger ones that are two-story houses, whose average height ranges between six to eight meters.

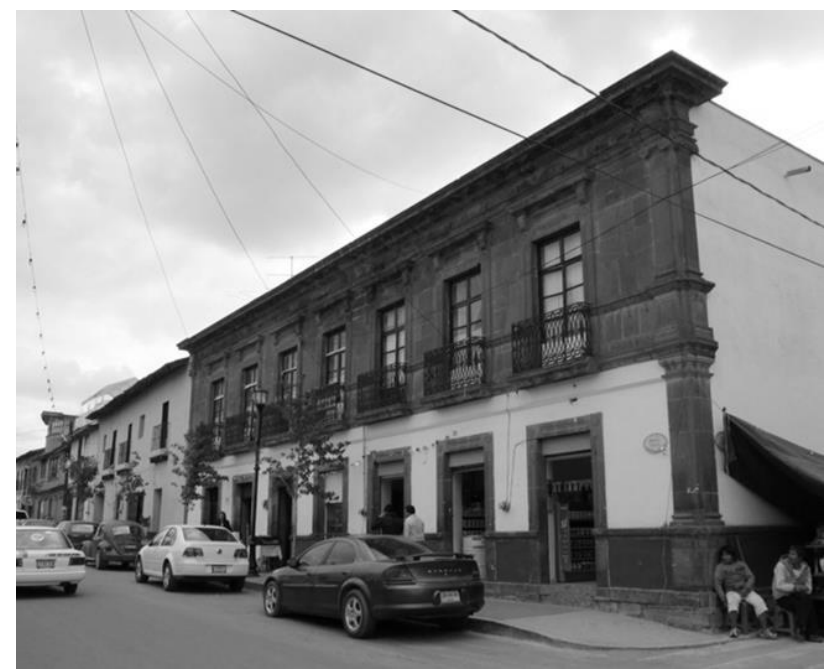

Figure 5. Two-story housing typologies. (Source: DSRO)

In all samples where there is gable roof, there are lofts built between the supporting structure and the cover of the rooms of the house. The loft is designed between wooden andirons and tile tilted roof, with flat roofs. This space was used as a cellar for keeping the seeds and products from agriculture; nowadays this area is not used or is the depot of some commerce.

On the decks that were thoroughly examined it was observed that, losing part of its constructive elements such as andirons or clay roof tiles, these elements have been replaced by new metallic structures and in the most unfavorable cases by thin plastic covers. The presence of these elements not only deteriorates the original image, but do not protect against the weather, resulting in moisture, water leaks, spills and loss of material. Unfortunately, only one-third of the buildings retains its original structure with exposed wooden beams and clay tiles in good condition.

The proportion opening-panels refers to the percentage that exists between the spaces constructed in its entirety, and areas where there are cavities: access, windows or vents. In one-story houses predominant openings in facade are the accesses to the building to the residential area and the accesses to shops, independent to the home. The openings for lighting, can be both simple holes in wall, or more complex elements such as smithy windows, have been used in smaller proportion.

The buildings tend to be closed to the outside and open up to the interior; domestic life happens in the courtyards. The proportion opening/wall is of a $10 \%$ of the total observable space on the facade, only one-third of the estate can occupy up to a $20 \%$ maximum in the facades. 
The ornamentation on the facade is quite simple, smooth walls. In some cases, the windows and doors have lintels and carved quarry door jambs; cornices of brick and stone quarry were observed as well. Gutters are made of steel and quarry stone, some of them garnished. Blacksmithing in windows and doors is simple and clean. The study identified that housing without quarry lintels prevail; lintels are made by wood covered with mud coating (enjarre) and in some cases instead of the wood, adobe (Figure 7).

For the finishing of the walls a three-type classification was made: 1 . No finishing due to the constructive system of wooden beams or pair and knuckle that does not allow space for the ornamentation; 2 . shows stone cornices and 3. cornices of red bricks are used. To finish the spatial shape classification, it has been determined that the era of construction covers the period from the $19^{\text {th }}$ to the $20^{\text {th }}$ century, but it also presents a few examples of the 18th century. Only $67 \%$ of the assets have an INAH's catalog tab; the other properties are not considered a patrimonial value and do not have any kind of protection.

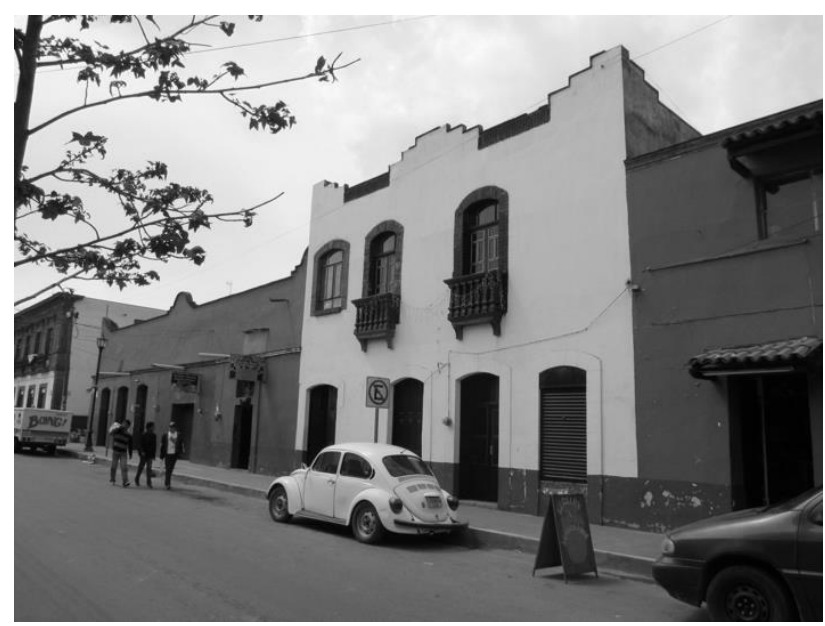

Figure 6. Two-story housing typologies. (Source: DSRO).

\subsection{Materials and building systems}

In the vast majority of examples analyzed in Calimaya, materials and construction techniques were identified; but in some areas, such as foundations, it was difficult to identify. What was possible is to observe is the use of lime-sand or cement-sand filing mortar.

During the study, we focused on five samples showing the most representative characteristics of the place. Boring holes were made in these buildings and the best working zones and those relevant were identified. The results showed that the foundation is made of flat stone found in the area. Foundation measures are 0.60 meters wide and 0.90 meters deep. In addition, the foundation protrudes out of the ground level 0.40 meters to prevent the adobes, corresponding to the carrier material of the structure, from having direct contact with the ground.

The most often used in Mexico traditional construction material is sandy soil; this was no exception, the walls are made of two different adobe types, the first one mixed with fibers and the second without them. The use of the adobe has predominated over other constructive systems by the ease of access to the material and the provision of water. These factors favor the election of the constructive system. The size of the adobes varies between $0.40 \times 0.20$ meters and $0.65 \times 0.40$ meters, with a height of 0.10 to 0.15 meters.

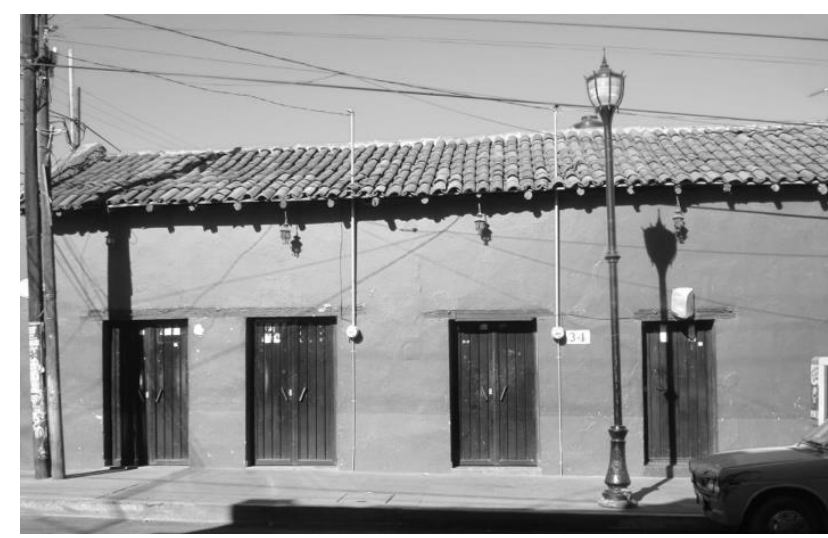

Figure 7. Type of facade simple in vernacular housing. (Source: DSRO).

The use of the earth is indistinct to socioeconomic status of the property; it has been used in all types of traditional housing. The mixed wall is the second type of identified constructive technique, which are carrying adobe elements with final touches in brick or local volcanic stone. Unfortunately, in the Calimaya outskirts, the more distance to the center there is, the prevailing building material is concrete block and covers; housings of vernacular origin presented changes that combined the traditional technique of adobe with contemporary constructive systems, resulting in a deterioration of the local image.

The mezzanines have been classified into: 1. loft of wooden beams of $0.15 \times 0.10 \mathrm{~m}, 5 \mathrm{~m}$ in length every $0.15 \mathrm{~m}$ between each one, filled with earth and covered with slabs of clay; and 2 . cover of concrete slab, where the original roofing has been modified by the owners (Figure 8).

We have identified three types of covers: a) wooden beams with clay tile; subdivided in roofs with a slope and covered with two slopes; b) concrete flat slab, which does not correspond with the original features; and c) collar beam roof with clay tiles.

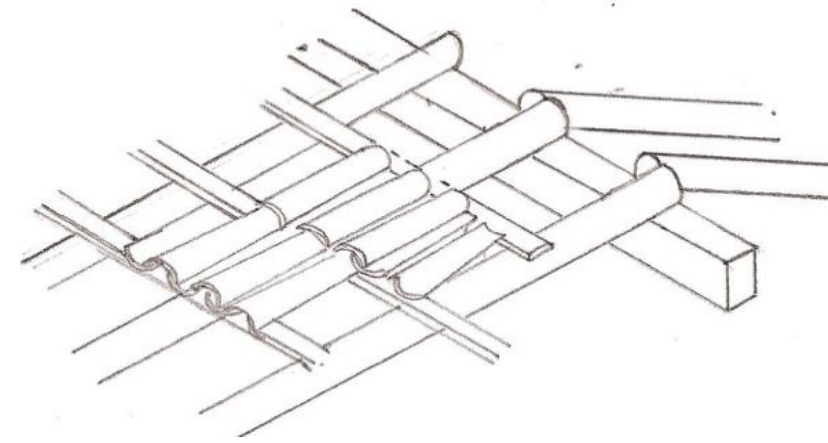

Figure 8. Sketch of constructive system typology.

(Source: own elaboration).

\section{CONCLUSIONS}

The possible application of the typology on built heritage has a virtually unlimited field. It can be of enormous value for cataloging, research, custody, maintenance, restoration, legal protection, teaching and dissemination. Although it is clear that all safeguarding measures are important and interrelated, the development of the stages of identification, documentation and registration are fundamental to set the variables and relationships to be considered in the other actions. 
The general concepts, recommendations, local laws and regulations that apply, in Mexico and other countries, are too restrictive in certain items and ambiguous in others, which makes confusing their interpretation and that ends up being a simple hierarchy of temporalities. These limitations complicate the preservation of the monumental works so it is even more complex their application in the field of vernacular architecture, which is generally not appreciated.

Therefore, the proper management of the typology may allow rising the small anonymous spaces to the same category of analysis and interpretation with the recognized monumental ensembles, taking them as constituent parts from the same urban or rural space. It is an instrument allowing an approach from a realistic and objective perspective, thus limiting the idealizations that are usually the result of subjective visions and that often do not agree with the community.

Adobe construction presents common typological traits everywhere in the world where it is performed. Wall widths, window size, habitable areas, and structural heights have shared boundaries that are derived from the strength of the adobes. However, in each region of the planet there have been unique ways of building with this material, which are the product of local geographical, historical and cultural conditions.

Typology is a methodological tool that allows recognizing common components and construction relationships and the singularly aspects of buildings. Both aspects are necessary to value the heritage qualities of architecture. In addition, the characterization of components and typological relationships allows distinguishing alterations in the works that affect their image but that can also be factors of structural vulnerability.

"To understand the question of type is to understand the nature of the architectural object today. It is a question that cannot be avoided. The architectural object cannot longer be considered as a single, isolated event because it is bounded by the world that surrounds it as well as by its history" (Moneo, 1978: 44).

The architectural typology provides the knowledge to continue constructive traditions that have proven their value simply because they have come to this day. It is a discipline that connects the past with the future through the identification of the rationale of the construction components, regardless of when they were realized.

\section{ACKNOWLEDGMENTS}

To Architect Jorge Alberto Pérez Nájera (JAPN), whose work has been fundamental to the conclusion of this work.

\section{REFERENCES}

Archivo Histórico de la Coordinación Nacional de Monumentos Históricos. México. INAH, Calimaya Parish Records.

Archivo Histórico de localidades, México. Instituto Nacional de Estadística y Geografía (INEGI).

Boils, G., 1982. Las casas campesinas en el porfiriato. México: SEP / Martin Casillas editores.

Caniggia, G., Maffei, G. L., 1995. Tipología de la edificación. Estructura del espacio antrópico. Madrid: Celeste.
Cortés, H., 1969. Cartas de Relación. México: Editorial Porrúa.

Gerhard, P., 1986. Geografía Histórica de la Nueva España 1519-1821. UNAM, México.

Guerrero Baca, L., 1998. Evolución de la tipología arquitectónica y urbana. México: UAM-Azcapotzalco.

Guerrero Baca, L. F., 1998. Tipología y conservación del Patrimonio Construido. Revista, En Síntesis, UAM-Xochimilco, 26.

Guerrero Baca, L. F., 2004. El valor tipológico del patrimonio edificado. Anuario de investigación y diseño, UAM. Xochimilco, 83-96.

Hernández Rodríguez, R., 2009. El Valle de Toluca. Época prehispánica y siglo XVI. México: Colegio Mexiquense.

Jarquín, M. T., 2006. El condado de Calimaya; documentos para la historia de una institución señorial. México: Instituto Mexiquense.

Loera Chávez, M., 1999. Monografía Municipal: Calimaya. México.

Loera Chávez, M., 1986. Calimaya. Época colonial. Secretaría de Educación, Cultura y Bienestar social, Dirección del patrimonio cultural, México.

Moneo, R., 1978, On typology, Oppositions, No. 13, p.p. 23-45.

Plan Municipal de Desarrollo Urbano de Calimaya 2009-2012. Gobierno del Estado de México: Secretaria de Desarrollo Urbano.

Rapoport, A., 1972. Vivienda y cultura. Milwaukee: University of Wisconsin. 